OBITUARY

\title{
IN MEMORY OF VLADIMLR NIKIFOROVICH VILYUNOV
}

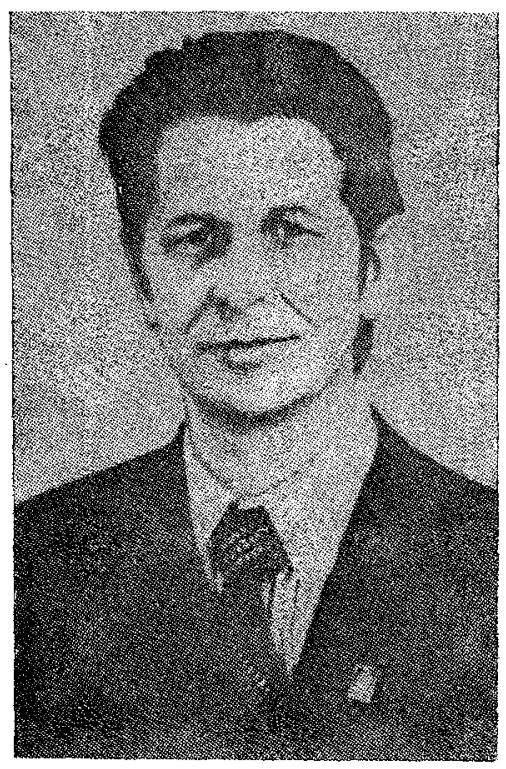

The eminent Soviet scholar and specialist in the field of macrokinetics and gas dynamics Vladimir Nikiforovich Vilyunov passed away at the age of 62 years on June 24, 1992. Vilyunov lived and worked his entire life in the city of Tomsk, remaining always a Siberian patriot and zealous advocate for development of Siberian industry and science.

Vilyunov's scientific activities commenced in 1953 upon his graduation from Tomsk State University, first at the Siberian Physicotechnical Institute, and then as chair of the mathematical physics department which he organized within the physics-technology faculty at Tomsk State. At the same time he served from the initial organization of the Scientific-Research Institute for Mathematics and Mechanics as scientific head of the gas dynamics-combustion physics division.

Even in his early studies on internal ballistics of artillery systems vilyunov received wide acclaim among specialists in his field. In the 1960 s Vilyunov's interests shifted to simulation and calculation of gas dynamics problems under conditions of rocket engine operation. He made a definitive contribution to the development of the theoretical foundation of mechanics and energetics for this class of thermal machines, including development of a multifaceted approach to equipment analysis and design. His approach included consideration of heat liberation processes during chemical reaction, heat exchange and gas dynamics of the products, extending as far as creation of an automatic design system. It was here that Vilyunov's innovative style first appeared, distinguishing his approach from a purely thermodynamic one as he produced pioneering studies in the gas dynamics of two-phase flows.

His wide view of technical problems did not hinder him from distinguishing salient questions having deep scientific significance from the overall spectrum. His was one of the first models of step-by-step combustion of condensed systems. Vilyunov's theory of combustion of powders and rocket fuels in a turbulent flow has seen wide acceptance. He discovered and identified the causes of anomalous combustion of solid fuel in a flow ("negative erosion"). Many experimenters have had recourse to his data in making use of the "Vilyunov parameter." His studies of combustion in a tubulent boundary layer led to his construction of an original mechanism for the influence of turbulence on gas combustion, related to the presence of temperature and component concentration pulsations.

Translated from Fizika Goreniya i Vzryva, Vol. 28, No. 5, pp. 134-135, September-0ctober, 1992 . 
Of special significance are Vilyunov's works on ignition theroy. The Vilyunov method for calculation of ignition characteristics is well known. He was one of the first to turn his attention to asymptotic methods for analysis of the non-linear equations of ignition theory. He developed a broad range of models and theoretical patterns for ignition. His works on ignition problems are among the classics, and his monographs, including those published abroad, have become desktop references for specialists in the field.

Vilyunov's interests were manifold, as reflected by his studies on hydromechanics, thermodynamics, chemical kinetics, and thermophysics.

However great was Vilyunov's own personal contribution to science, his main achievement was most probably the development of a Siberian school of macrokinetics, his organization of science cadres at Tomsk State University and the Scientific Research Institute for Applied Mathematics and Mechanics. Among his students there have been more than 60 attaining the candidate's degree and 12 doctors of science, which by no means exhausts his influence on the development of Siberian science, since many students who did not study directly under Vilyunov nevertheless experienced his magical influence, being infected by his ideas and the excitement of scientific research.

During the entire life of Fizıka Goreniya i Vzryva Vilyunov took an active part in the journal's activities, as one of its most qualified reviewers, and since 1989, as a member of the editorial board.

In the last years of his life Vilyunov received a series of awards expressing society's recognition of his labors - he was awarded the Order of Peoples' Friendship, state medals and honorary medals from the USSR Cosmonautics Federation. He was awarded the title of Devoted science and technology activist for the RSFSR and was selected as a corresponding member of the Russian Academy of Natural Sciences.

Every person who had the good fortune to meet or work with Vladimir Nikiforovich will recall foremost his warm humanistic presence, the high principles to which he held, his warm interest in his coworkers, and his dedication to science. Many of those who with deep grief heard of Vilyunov's passing see in him an example of a life well lived.

His Colleagues, Students, and the Editorial Board 